\title{
USING ACTIVE LEARNING METHODOLOGIES IN AN INTRODUCTORY STATISTICS COURSE
}

\author{
ANNA REGINA CORBO \\ Centro Federal de Educação Tecnológica Celso Suckow da Fonseca (CEFET/RJ), Brasil \\ anna.costa@cefet-rj.br \\ DANIEL GUILHERME GOMES SASAKI \\ Centro Federal de Educação Tecnológica Celso Suckow da Fonseca (CEFET/RJ), Brasil \\ daniel.sasaki@cefet-rj.br
}

\begin{abstract}
In general, engineering students show little interest in the activities inherent in statistics subjects. This claim may be partly explained by the competition with other subjects in the first years of undergraduate courses, or by student perceived low attractiveness of the classes. In this context, several studies indicated that methodologies where the student is the protagonist of the learning process lead to greater engagement during the activities and better scores in the assessments. This work describes the use of active learning methodologies in an introductory probability and statistics course for Engineering classes at a Brazilian public institution. Two classes were monitored during one term: in the first one (control class) traditional lectures were used, in the second one (experimental class) three different active methodologies were applied, namely: Jigsaw, Peer Instruction and Think-Pair-Share. On the one hand, the results indicated slightly better performances in the experimental class, as well as an increase in attendance. On the other hand, dropout rates were similar in both classes. This study is part of a renewal proposal of the mathematics subjects, based on the use of active learning methodologies and the review of curricular content to meet current pedagogical demands.
\end{abstract}

Keywords: Statistics education research; Active learning; Jigsaw; Peer instruction; Think-pairshare

\section{INTRODUCTION}

The importance of teaching statistics at higher education level can be recognized by the contribution of training qualified professionals to properly plan and develop process and research in different areas. Thus, statistics is part of the curriculum of undergraduate courses in the Exact, Biological and Human Sciences areas. However, it is common to find unmotivated students in the classroom. One of the reasons may be the gap between the theory presented in class and its application in professional life.

Pointed out by Morettin et al. in 1985, were concerns about teaching statistics in Latin America in relation to the existing gap between academic instruction and the needs of National Statistical Offices (NSO's), business, and industry. Additionally, Haedo (2006), mentioned that some of the main problems that affect teaching and research in statistics in the South American countries, are: difficulty accessing research literature, pedagogical materials, and technology at the University level; misuse of advanced calculators and computers at the different educational levels; emphasis on probability theory rather than data analysis; strong mathematical background of statistics teachers; and lack of investment in the maintenance and modernization of the institutions' infrastructure.

Moreover, the academic teaching process should be based not only on implementing the curriculum, but also on fostering and developing the so-called 21st century skills for education: collect of information, communication, collaboration, creativity, critical thinking, and ethics. Then, aligned with the growing evolution of available teaching resources, expositive lectures must be revised to meet the demands of a much more dynamic and challenging social, economic, and technological context.

Our research is part of a context in which these 21 st century skills, which go beyond academic knowledge, are required from students on graduation. Furthermore, working together has been 
increasingly necessary in an interdisciplinary global job market, making the gap cited by Morettin et al. (1985) deeper when these skills are not developed.

In addition, Brazilian Law No. 12,711 of 2012, called the Quota Law, stated that federal higher education institutions, federal schools and vocational education institutions must reserve $50 \%$ of their places for quotas (BRASIL, 2012). This law aimed to reduce inequality of opportunities, contributing to make the distribution of different strata of society in the Brazilian public university fairer, plural, and egalitarian. Thereby, since half of the students in federal educational institutions come from the quota system, it would be interesting to consider this variable in the analysis of this study.

Several studies have been developed in Brazil (Viali \& Vaccaro, 1999; Ara \& Musetti, 2001; Alves et al., 2004, Barbosa et al., 2018) aimed at the revision of standard contents of statistics courses and incorporation of new procedures, especially those directed to the design, execution, and analysis of experiments. However, most of these studies are often restricted to the insertion of computational resources in the classroom activities. However, learning improves when focus shifts from the individual to the group (Marzano, 2003; Slavin, 1995).

The expression collaborative learning has been used to characterize a methodology for the teaching-learning process involving group work, with the aim of socializing and building knowledge, mediated by an instructor (Dillenbourg, 1999). In turn, a cooperative method is based on group success rather than individual success. Cooperation has a specific meaning described in the theoretical framework of cooperative learning proposed by Johnson and Johnson (1989). Cooperation is a specific form of collaboration that has three central characteristics: positive interdependence, individual responsibility, and group processing (Stahl, 1996; Holliday, 2000). Each student in the group must necessarily be a source of peer learning as he or she explains a part of the content. Therefore, a student has responsibility for their own learning and still must actively contribute to the development of their team. Group processing is performed by the students themselves through periodic qualitative balances of the activities, behaviors, and attitudes of each team member.

In statistics, we can mention the work developed by Roseth et al. (2008) where is presented a guide for statistics educators aiming at the application of a cooperative framework in the classroom. In that work, the authors point out that although the idea is simple, it is not simple to implement a cooperative learning method. One of the authors' goals was to highlight specific ways in which cooperative methods can be implemented in statistical education and address the concerns of those statistical educators who are reluctant to adopt student-centered teaching strategies.

The research presented in this manuscript describes the implementation of collaborative and cooperative methodologies to teach introductory Statistics for Engineering classes, at a federal Brazilian higher education institution. Three different active methodologies for different topics (in brackets) were used: Jigsaw (Sampling), Think-Pair-Share (Continuous Random Variables) and PeerInstruction (Confidence Interval).

\subsection{THINK-PAIR-SHARE}

The Think-Pair-Share (TPS) methodology was developed by Frank Lyman in the USA in 1981 (McTighe \& Lyman, 1988) and has been described and adapted by educators such as Ledlow (2001) and Kothiyal (2013), among others. TPS is a collaborative method in which students exchange ideas and knowledge with their peers and intend to encourage student participation and discussion in groups. This learning strategy includes three components: time to think, time to share with only one colleague, and time to share in a larger group.

This method consists of the following four steps: a) Problematization: the instructor provides students with a problem related to content; $b$ ) Thinking: students should think about the question for a time determined by the instructor that is compatible with the class dynamics; c) Pairing: Students share their ideas with fellows in small groups; d) Sharing: Students share their answers in larger groups or with the whole class. This method is simple and easy to apply and can be used with an entire class or part of it. 


\subsection{JIGSAW}

The Jigsaw methodology was developed by Aronson in 1971 in the USA to foster and improve interaction between students from different social backgrounds through dynamics in small and mixed groups (Aronson \& Patnoe, 1997). Jigsaw is a cooperative learning technique where each student is responsible for teaching a topic to his/her group members and thereby developing skills such as communication, cooperation, critical thinking and mutual respect. Numerous improvements of the original method have been proposed and currently there are several types of Jigsaw, such as: Jigsaw I by Aronson (1978), Jigsaw-II (Slavin, 1987), Jigsaw-III (Stahl, 1996), Jigsaw-IV (Holliday, 2000) and Reverse Jigsaw (Heeden, 2003). In Brazil, there are few reports of the use of this methodology in the exact sciences area. Among them we highlight Fatarelli et al. (2010), Leite et al. (2013) and Gomes (2015).

In applying the Jigsaw method, the instructor intervenes very little, as there are no lectures. First, the class is divided into heterogeneous groups of 4 to 6 students, called base groups. The instructor is responsible for preparing and dividing the topic into several equivalent topics that correspond to the typical number of students in the base groups. Each student in the base group is given a different topic and should study it before meeting in another group of peers responsible for the same topic, called the expert group. In the expert group, students discuss the same topic that they will then have to explain to their peers in their base groups. A summative assessment is performed at the end of the class. Students are expected to engage themselves to understand and teach curriculum knowledge.

In statistics, we can mention the work of Perkins and Saris (2001) who used the Jigsaw methodology in a worksheet activity. These authors compared the average scores between classes prior to the use of Jigsaw with classes that used this technique. The authors found a slight improvement in the performance of classes using the active learning methodology, as well as an improvement in social skills development and class time savings with the division of tasks.

Carey and Dunn (2018) believe that language development is as important as mathematical calculations in statistical education. The authors describe the training of a group of Statistics lecturers to implement the TPS and Jigsaw techniques in the classroom. They reported that the techniques were well received by almost all lecturers and that the audience who effectively used the active methodologies observed greater student engagement during the activities, which also could be observed in our study. The authors conclude that applying language-focused methodologies, while requiring effort and planning, is beneficial for improving communication for both students and instructors.

\subsection{PEER INSTRUCTION}

The Peer Instruction (PI) collaborative methodology was developed in the 1990s by Mazur at Harvard University (Mazur, 1997). The method has been widely applied preferentially in universities around the world. With Peer Instruction, the instructor gives a brief oral presentation focused on the fundamental concepts and then poses a conceptual question for students to answer individually. According to the percentage of correct answers in the class, a quick debate can be established between students who have different opinions, organized in small groups. Then new student responses are collected for the same question. In the following, the instructor explains the question and restarts the process of dialogical exposition of the next theme. According to Smith et al. (2009), there is evidence of learning gains, even when there is discussion among colleagues, without any of them having chosen the correct answer previously. Some studies in Brazil have been developed using this methodology. For example, Araujo and Mazur (2013), Dumont et al. (2016), and Carvalho et al. (2018).

\section{METHODOLOGY}

This work was conducted with two undergraduate statistics classes for an Engineering course at a federal Brazilian public institution in the first semester of 2019. Both groups had the same instructor (the first author of this work), which employed different teaching methodologies throughout the semester. The assessments given were the same for both classes. 
The Statistics course curriculum at this institution consisted of Descriptive Statistics (population and variables; numerical and graphical methods), Probability, Discrete and continuous random variables and their probability distributions, Normal Distribution, Sampling and Estimation (types and size of sampling, sampling distributions and point estimation), Confidence Intervals (mean with variance known, with variance unknown and proportion) and Introduction to Hypothesis Testing. The course was offered in a single semester course given at the beginning of the second year with weekly workload of 2 hours and 30 minutes.

In the first half of the semester, identical traditional lectures were given to both groups. After the first exam, the classes were classified as: a) Control Class, where the classes remained traditional; and b) Experimental Class, where the three methodologies previously described were used for the following topics: Think-Pair-Share (for Continuous Random Variables), Jigsaw (for Sampling) and Peer-Instruction (for Confidence Interval). The control class had 30 students and the experimental class 28 students.

It is important to note that studies in the classroom environment may have different types of bias, especially selection bias and measurement bias. The random choice of the experimental class was intended to eliminate the selection bias. The application of the same evaluations and extra class activities for both groups were a way to reduce the impact of the measurement bias on the results. However, performing a double-blind test in this type of study is not feasible and the possibility of the Pygmalion effect, described by Rosenthal and Jacobson (1968), is a reality. These authors showed that instructors' expectations influence student behavior, causing an involuntary effect on the performance of the class or part of it.

In order to evaluate the performance of both groups, the score average of each class in the first and second exam were analyzed. The performance of quota and non-quota students was also evaluated. In the control class, among the 30 students enrolled, 11 were quota students and 19 nonquota students; In the experimental class, the 28 students were equally divided as quota and non-quota students.

Two other factors evaluated in this work were the attendance in both classes (here, the frequent student is the one who attended more than $75 \%$ of the meetings) as well as the percentage of dropout recorded (here, the evasive student is the one who did not perform evaluations). Note that, in this classification, a student can be considered frequent (he or she was in more than $75 \%$ of the meetings), but also be considered as a dropout student (made no assessments), that is, the two groups analyzed are not exclusive.

At the end of the course an anonymous survey about students' opinions on the Statistics course with use of active learning methodologies was applied in the experimental class. The elaboration of the questionnaire was based on the work of Fatareli et al. (2010) and contained the seven following statements:

- I worked harder on active methodology than I usually work during traditional classes.

- I prefer when the teacher discusses topics with the whole class (traditional class) than when we must work in groups.

- I enjoyed working with active methodologies because I was able to work together with colleagues.

- Using different teaching methods makes our classes more fun and less tiring.

- I consider that the final quiz at the end of the class is important for the progress of class activities.

- The type of teaching methodology used in class influences my performance in assessments.

- I would like to participate again in classes with active learning methodologies.

The answers followed the Likert scale options: 1-Strongly Disagree, 2- Disagree, 3- Neutral, 4Agree and 5-Strongly Agree. In total, 16 students from the experimental class answered the survey.

\subsection{USE OF ACTIVE METHODOLOGIES IN THE CLASSROOM}

In this section we describe the implementation details of the three active learning strategies used in this study. 
Continuous Random Variables (Think-Pair-Share). In this class, 21 students were present. The technique was used twice during the introductory lecture of continuous random variables.

At first, after a 30-minute lecture, it was proposed to students to define the random variable that modeled the contextualized problem and to use the given density function to perform probability calculations (without previous examples). The class was divided into 9 pairs and 1 trio. Students had 1 minute to read and think about the question individually. Then each pair had 6 minutes to solve the question. After this time, the pairs could freely group into 4 groups of 4 students and 1 group of 5 students. In this new grouping, the pairs had 5 minutes to share their solution with another pair and reach consensus on the group's final response. At the end of this stage, the instructor corrected the question by considering that part of the students solved the question graphically and part analytically, thus concluding a global answer. A brief procedural question was chosen to familiarize students with the methodology. This step took 20 minutes of class. The problem proposed is presented in Table 1.

In the second moment, after another 40-minute lecture, it was proposed to deduce the expression of expected value and variance of a continuous random variable, from the expression in the discrete case. Again, the class was divided into 9 pairs and 1 trio. Students had 1 minute to read and think about the question individually. As in the first moment, each pair had 6 minutes to resolve the question. After this time, the pairs were grouped into 4 groups of 4 students and 1 group of 5 students. However, this time the instructor defined the groups. The criterion was to pair up pairs that usually position themselves in opposite locations in the classroom making students move around the space and work with new classmates.

In these groups, the pairs had 5 minutes to share their solution with the other pair and reach consensus on the group's final response. At the end of the stage, the instructor corrected the question. The question proposed at this stage is also presented in Table 1. It should be noted that the second question was more conceptual than the first one. Consequently, students had more difficulty completing the task. In total, the Think-Pair-Share class lasted about 2 hours.

Table 1. Questions proposed during the application of the TPS method

\begin{tabular}{cl}
\hline Question & \multicolumn{1}{c}{ Statement } \\
\hline 1 & The return time of an acoustic signal, in seconds, is modeled by the density \\
function $\mathrm{f}(\mathrm{x})=1.5 \mathrm{x}^{2}$, where $-1<\mathrm{x}<1$. \\
a) What is the definition of the random variable that models this problem? \\
b) What is the probability of the return time to be positive? \\
a) From the expression for the case of a discrete random variable, deduce the \\
expression for the $\mathrm{E}[\mathrm{X}]$ and $\mathrm{V}[\mathrm{X}]$ of a continuous random variable. \\
b) What is the meaning of the expression found for the expected value of a \\
continuous random variable?
\end{tabular}

Sampling (Jigsaw). In this class, 17 students were present. The content was divided by the instructor in four topics, namely:

(1) Non-probability sampling methods (convenience, judgmental and voluntary).

(2) Probability sampling methods (simple random, systematic random and stratified).

(3) Calculation of all possible samples and calculation of sample size.

(4) Introduction to sample distribution of means.

It is important to note that engineering courses in Brazil generally offered little gender diversity. There are very few girls enrolled in this type of course. For example, in the experimental class, only 4 out of 28 students were women. Thus, the creation of heterogeneous gender groups, as proposed by the methodology, is practically impossible. One option would be to form groups by mixing quota and non-quota students. However, the instructor noted that this social division was not so evident throughout the course and it was decided to let the groups form freely.

The students were divided into 3 groups with 4 students and one group with 5 students, in total, four base groups. In each base group, each student received the material edited by the instructor on one of the topics (in the group of 5 students, two students received topic 4). 
The first moment consisted of the individual reading of the topic, which was performed in 8 minutes. Then the students left their initial base groups and formed the so-called expert group: a group of students with the same subject. In the expert group, they should discuss the topic and respond as a group to a set of guiding questions (conceptual and operational) on that subject. Students concluded the stage in 35 minutes.

In the next moment, the students returned to their initial base groups. Each student was responsible for presenting his subject clearly and explained the questions (especially the conceptual ones) to their colleagues. The instructor listened to the explanations and intervened when necessary. This step had a total time of 39 minutes.

Finally, an individual summative assessment was applied. This assessment was in form of multiple choices, with a conceptual question for each topic. At the beginning, students were advised about this assessment in order to stimulate student participation in all stages of the methodology. In total, the class with the Jigsaw methodology was concluded in 1 hour and 45 minutes.

Confidence Interval (Peer Instruction). For this class, three conceptual questions were elaborated to be debated during the class. They focus on the main purpose of a Confidence Interval, on the relationship between margin of error, level of significance, and sample size, and on deciding which interval to use in a problem situation. The questions are presented in Table 2.

\section{Table 2. Questions proposed during the application of the PI method}

\begin{tabular}{cl}
\hline Question & \multicolumn{1}{c}{ Statement } \\
\hline 1 & A confidence interval estimate has as its main objective: \\
(a) Ensure that the researcher always gets it right. \\
(b) Ensure that research never goes wrong. \\
(c) Bring the research result closer to population value. \\
(d) Calculate margin of error for sample estimation \\
Which option is true? \\
(a) The margin of error quantifies the chance that the confidence interval is wrong. \\
(b) The significance level quantifies the radius of the confidence interval. \\
(c) The size of the interval is inversely proportional to the number of samples. \\
(d) Significance is directly proportional to the radius of the interval. \\
When launching a new handset model, it is necessary to statistically prove that its \\
noise level is less than 15 decibels. What kind of confidence interval should we use? \\
(a) Mean with known population variance. \\
(b) Mean with unknown population variance. \\
(c) Proportion.
\end{tabular}

In this activity, 20 students were present. The content was divided into three small lectures and the first one lasted 20 minutes. It aimed to introduce the concept of confidence interval and an overview of existing basic types. During the application of the first conceptual test, students had 2 minutes to answer the question individually. Seventy percent of the students hit the question and this test was closed.

The second lecture lasted 25 minutes and was about the relationship between margin of error, level of significance, confidence, and sample size. After the lecture, the second individual conceptual test was applied and, after 2 minutes, $68 \%$ of the students answered the question correctly. According to the proposed methodology, groups of 2 to 3 students were formed, where at least one should have marked a different option from the others. After another 2 minutes, the same individual test was applied, and the hit percentage increased to $100 \%$.

The last lecture lasted 50 minutes and aimed to deduce the formulation for the confidence interval for the population mean with and without known variance and the confidence interval for population proportion. After the lecture, the third conceptual question was presented and again the students had 2 minutes to answer it individually. As the ratio for correct answers for this question was $56 \%$, the students were again grouped to discuss the question for another 2 minutes. The conceptual test was 
applied again to the class with a 95\% success rate. In total, the class using the Peer Instruction methodology lasted about 2 hours and 5 minutes.

\section{RESULTS AND DISCUSSION}

Table 3 compares the evolution of the score average among the first and second exams of the two classes analyzed. Only the grades of the students who made the two exams in each class were used. In this condition, there were 18 students in the control class and 17 students in the experimental class. The table also shows separately the evolution of performance among quota and non-quota students.

The Normalized Performance Variation (PV) was calculated from an adjustment of the methodology proposed by Hake (1998), where PV is calculated as a percentage of the evolution of the scores obtained in the first exam (E1) and the second exam (E2), given as follow:

(1) $P V=\frac{E 2-E 1}{10-E 1}$

Table 3. Average of exams scores and normalized performance variation of control and experimental classes

\begin{tabular}{llccc}
\hline & & Exam 1 & Exam 2 & Performance Variation \\
\hline Control Class & General & 7.161 & 7.189 & $0.98 \%$ \\
& Quota students & 6.18 & 7.76 & \\
Experimental Class & Non-quota students & 7.538 & 6.969 & \multirow{1}{*}{ General } \\
& Quota students & 8.088 & 8.376 & \\
& Non-quota students & 8.057 & 7.743 & \\
\hline
\end{tabular}

Regarding student attendance, a total of 22 out of 30 students were registered with attendance above $75 \%$ of the course in the control class. In the experimental class, 25 of 28 students were classified as frequent students. Table 4 shows, as a percentage, the total number of frequent students, as well as the registered attendance of quota and non-quota students.

Table 4. Attendance rates in control and experimental classes

\begin{tabular}{lccc}
\hline & General & Quota students & Non-quota students \\
\hline Control Class & 73.33 & 81.81 & 68.42 \\
Experimental Class & 89.28 & 85.71 & 92.85 \\
\hline
\end{tabular}

When analyzing dropout, both classes registered 6 dropout students. It is important to note that there are students who attended more than $75 \%$ of the meetings, but they were considered as dropout students (as they did no evaluation). Table 5 shows the percentage of students who drop out in each group, as well as those who drop out in quota and non-quota students.

Table 5. Dropout rates in control and experimental classes

\begin{tabular}{lccc}
\hline & General & Quota students & Non-quota students \\
\hline Control Class & 20.00 & 18.18 & 21.05 \\
Experimental Class & 21.42 & 28.57 & 14.28 \\
\hline
\end{tabular}

To analyze the efficiency of active methodologies, a t-test with $95 \%$ confidence was conducted for identifying differences between the means of the second exam in each class, when there were different learning methodologies. By analyzing the means of the 18 students who made the two exams in the control class, the average was 7.189 and in the experimental class, for the 17 students who 
performed the two exams, the average obtained was 8.376, according to the data in Table 3. From the test performed, it can be concluded that the average in the second exam for experimental class is higher with $p=0.05906$.

Table 6 shows the responses regarding students' opinions about the experimental classes. Overall, $81.25 \%$ of respondents believe there was more participation during active classes, $68.75 \%$ enjoyed working in groups, $87.5 \%$ found the class more fun and less tiring and $87.5 \%$ would like to participate in more active classes. Although $62.5 \%$ of students believed that the type of methodology used influenced their performance, $50 \%$ did not want to define the preference between lectures or classes with active learning methodologies. In our bibliographical research, it was possible to find a only a few works applying active methodologies in statistics education, especially articles that analyzed students' performance after the use of these learning methodologies.

Table 6. Percentage analysis of the students' opinions in the experimental class (1-Totally Disagree; 2-Disagree; 3-Neutral; 4-Agree; 5-Strongly Agree)

\begin{tabular}{lcccccc}
\hline \multicolumn{1}{c}{ Statement } & 1 & 2 & 3 & 4 & 5 \\
\hline $\begin{array}{l}\text { I worked harder on active methodology than I } \\
\text { usually work during traditional classes. }\end{array}$ & 0.0 & 0.0 & 18.75 & 43.75 & 37.5 \\
$\begin{array}{l}\text { I prefer when the teacher discusses topics with the } \\
\text { whole class (traditional class) than when we must }\end{array}$ & 12.5 & 0.0 & 50.0 & 18.75 & 18.75 \\
$\begin{array}{l}\text { work in groups. } \\
\begin{array}{l}\text { I enjoyed working with active methodologies } \\
\text { because I was able to work together with other } \\
\text { colleagues. }\end{array}\end{array}$ & 6.25 & 12.5 & 12.5 & 25.0 & 43.75 \\
$\begin{array}{l}\text { Using different teaching methods makes our } \\
\text { classes more fun and less tiring. }\end{array}$ & 0.0 & 6.25 & 6.25 & 25.0 & 62.5 \\
$\begin{array}{l}\text { I consider that the final quiz at the end of the class } \\
\text { is important for the progress of class activities. }\end{array}$ & 0.0 & 6.25 & 12.5 & 6.25 & 75.0 \\
$\begin{array}{l}\text { The type of teaching methodology used in class } \\
\text { influences my performance in assessments. }\end{array}$ & 0.0 & 0.0 & 37.5 & 18.75 & 43.75 \\
$\begin{array}{l}\text { I would like to participate again in classes with } \\
\text { active learning methodologies. }\end{array}$ & 0.0 & 6.25 & 6.25 & 25.0 & 62.5 \\
\hline
\end{tabular}

The results obtained here were like those in the study conducted by Perkins and Saris (2001). It was found that our students' opinions about the three methodologies used were similar to the results obtained in that study, which reported the following benefits of using Jigsaw. Based on a survey using Likert scale: $55 \%$ enjoyed working with colleagues, $88 \%$ appreciated the use of different teaching methodologies, and $85.7 \%$ would like to rejoin Jigsaw classes.

Corroborating the work of Carey and Dunn (2018), our study observed that language development was encouraged in all methodologies used. Indeed, the emphasis to communication stands out during the discussions promoted in the PI and TPS methodologies, since, in both methods, one of the steps is to use this skill individually to process and formulate a new concept to colleagues in a short period of time.

\section{CONCLUSIONS}

The results indicated better academic performance in the evaluations of the experimental class, despite the low number of students involved in the study. In fact, the experimental class had a $15.06 \%$ improvement between the first and second exam, while the control class remained practically stable, with a $0.98 \%$ improvement between the first and second exam. However, the use of active methodologies did not reduce classroom dropout, a problem so common in universities. In both classes, the percentage of students who did no assessment during the course was around $20 \%$.

The percentage of effectively frequent students was significantly higher in the experimental class than in the control class. In the control class, around $73 \%$ of the class attended most of the course. In 
the experimental class, nearly $90 \%$ of the class attended $75 \%$ or more of weekly meetings. Additionally, the experimental group appreciated the proposed activities and dynamics, with $87.5 \%$ of the students classifying the course classes as more fun and less tiring.

It is also possible to observe that, in the experimental class, the performance of quota students was not significantly different from non-quota students, with averages very close in the second evaluation, which corresponds to the period of application of active methodologies. Therefore, the improvement in the overall performance of the experimental class when compared to the control class, between the two evaluations, was mainly due to the performance of non-quota students.

This work indicated that these internationally recognized active methodologies can be successfully applied in a Brazilian context where classes are socially mixed and when there are no appropriate materials available and reliable online tools, for all students or teachers. Our study also revealed that the social and academic impact of using active learning methods in the classroom is auspicious for both regular students and students benefiting from affirmative policies. A difficulty for the wide and systematic implementation of these techniques, according to Roseth et al. (2008), is the necessary engagement of part of the lecturers who often, in Engineering courses in Latin America, as pointed by Haedo (2006), have a strong mathematical background, as well a strong reluctance in the application of student-centered learning activities.

Finally, we emphasize that the systematic use of three different active learning methodologies made the students more motivated by encouraging their engagement and the development of skills not directly related to the curriculum, such as collaboration, cooperation, communication, creativity, and critical thinking.

\section{REFERENCES}

Aronson, E. (1978). The jigsaw classroom. SAGE Publications.

Aronson, E., \& Patnoe, S. (1997). Cooperation in the classroom: The jigsaw method (2nd ed.). Addison-Wesley.

Araujo, I., \& Mazur, E. (2013). Instrução pelos colegas e ensino sob medida: Uma proposta para o engajamento dos alunos no processo de ensino-aprendizagem de Física. Caderno Brasileiro de Ensino de Física, 30(2), 362-384.

Alves, M. I. F., Montebello, M. I. de L, Lacerda, T. H., \& Santore, M. O. C. (2004). Uma proposta para o ensino de Estatística nos cursos de Engenharia. Proceedings of $16^{\circ}$ Simpósio Nacional de Probabilidade e Estatística (SINAPE), Caxambu/MG, Brasil.

Ara, A., \& Musetti, A. (2001). Avaliação de uma nova metodologia no ensino de Estatística para o curso de Engenharia. Proceedings of XXIX Congresso Brasileiro de Ensino de Engenharia (COBENGE). (pp. 246-250), Porto Alegre/RS, Brasil.

BRASIL. Lei $\mathrm{N}^{\mathrm{o}} 12.711$, de 29 de agosto de 2012. Lei de Cotas, Brasília, DF. http://www.planalto.gov.br/ccivil_03/_ato2011-2014/2012/lei/112711.htm

Barbosa, M., Rosa, A., Velasque, L., Oliveira, A., \& Esteves, F. (2018). Avaliação de ensinoaprendizagem em uma metodologia ativa de ensino em Estatística: um estudo usando grupo focal e metodologia Delphi. Proceedings of $23^{\circ}$ Simpósio Nacional de Probabilidade e Estatística (SINAPE), São Pedro/SP, Brasil.

Carvalho, E., Silva, D., Catuogno, C. R., \& Romão, E. (2018). Metodologias ativas no ensino fundamental: Uma experiência com o peer instruction. Revista Inova Ciência Tecnologia, 4(1). http://periodicos.iftm.edu.br/index.php/inova/article/view/399

Carey, M., \& Dunn, P. (2018). Facilitating language-focused cooperative learning in introductory statistics classrooms: A case study. Statistics Education Research Journal, 17(2), 30-50. https://doi.org/10.52041/serj.v17i2.157

Dillenbourg, P. (1999). What do you mean by collaborative learning? In P. Dillenbourg (Ed.). Collaborative-learning: Cognitive and computational approaches (pp. 1-19). Emerald Group Publishing.

Dumont, L., Carvalho, R. \& Neves, A. (2016). O Peer Instruction como proposta de metodologia ativa no ensino de química. Journal of Chemical Engineering and Chemistry, 2(3), 107-131.

Fatareli, E., Ferreira, L., Ferreira J., \& Queiroz, S. (2010). Método cooperativo de aprendizagem jigsaw no ensino de cinética química. Química Nova, 32(3), 161-168. 
Gomes, E. (2015). Contribuições do método jigsaw de aprendizagem cooperativa para a mobilização dos estilos de pensamento matemático por estudantes de engenharia. (Unpublished doctoral dissertation) Pontifícia Universidade Católica de São Paulo, São Paulo.

Haedo, A. S. (2006). Cooperation in research and in teaching statistics in Argentina. In A. Rossman \& B. Chance (Eds.), Working cooperatively in statistics education. Proceedings of the Tenth International Conference on Teaching Statistics (ICOTS-7, July 8-13, 2016), Salvador, Brazil. International Statistical Institute.

Hake, R. R. (1998). Interactive-engagement versus traditional methods: A six-thousand student survey of mechanics test data for introductory physics courses. American Journal of Physics, 66(1), 6474. https://doi.org/10.1119/1.18809

Hedeen, T. (2003). The reverse jigsaw: A process of cooperative learning and discussion. Teaching Sociology, 31(3), 325-332. https://doi.org/10.2307/3211330

Holliday, D. C. (2000). The development of jigsaw IV in a secondary social studies classroom. Proceedings of 2000 Midwest Educational Research Association (MWERA) Annual Conference, Chicago.

Johnson, D. W., \& Johnson, R. T. (1989). Cooperation and competition: Theory and research. Interaction Book Company.

Leite, I., Lourenço, A., Licio, J., \& Hernandes, A. (2013). Uso do método cooperativo de aprendizagem Jigsaw adaptado ao ensino de nanociência e nanotecnologia. Revista Brasileira de Ensino de Física, 35(4), 1-7.

Ledlow, S. (2001). Using think pair share in the college classroom. Arizona State University.

Kothiyal, A., Majumdar, R., Murthy, S., \& Iyer, S. (2013). Effect of think-pair-share in a large CS1 class: 83\% sustained engagement. In B. Somin, A. Clear \& Q. Cutts (Eds.), ICER'13. Proceedings of the ninth annual international ACM conference on International computing education research (pp. 137-144), San Diego. https//doi.org/10.1145/2493394.2493408

Marzano, R. J. (2003). What works in schools: Translating research into action. ASCD.

Mazur, E. (1997). Peer instruction: A user's manual. Prentice Hall.

McTighe, J., \& Lyman, F. T. (1988). Cueing thinking in the classroom: the promise of theoryembedded tools. Education Leadership, 45(7),18-24.

Morettin, P. A., Peres, C. A., Narula, S. C., \& Mentz, R. P. (1985). Statistics in Latin America. The American Statistician, 39(4), 274-278.

Perkins, D., \& Saris, R. (2001). A jigsaw classroom technique for undergraduate statistics courses. Teaching of Psychology, 28(2), 111-113.

Rosenthal, R., \& Jacobson, L. (1968). Pygmalion in the classroom. Holt, Rinehart e Winston.

Roseth, C. J., Garfield, J. B., \& Ben-Zvi, D. (2008). Collaboration in learning and teaching statistics. Journal of Statistics Education, 16(1). https://doi.org/10.1080/10691898.2008.11889557

Slavin, R. E. (1987). Cooperative learning: Where behavioral and humanistic approaches to classroom motivation meet. Elementary School Journal, 88, 9-37.

Slavin, R. (1995). Cooperative learning: Theory, research, and practice, (2nd ed.), Allyn \& Bacon.

Stahl, R. J. (1996). Cooperative learning in science: A handbook for teachers. Addison-Wesley.

Smith, M. K., Wood, W., Adams, W., Wieman, C., Knight, J., Guild, N., Su, T. (2009). Why peer discussion improves student performance on in-class concept questions. Science, 323(5910), 122 124.

Viali, L., \& Vaccaro, G. (1999). Os novos recursos computacionais e o ensino de estatística para as engenharias. Proceedings of XXVII Congresso Brasileiro de Ensino de Engenharia (COBENGE) (pp. 289-296). Natal/RN, Brasil.

MAIN AUTHOR:

Anna Regina Corbo

Avenida Maracanã, 229 - Rio de Janeiro - RJ

Brazil

CEP: 20271-110

E-mail: anna.costa@cefet-rj.br 